\title{
REPRESENTASI CITRA POLITISI PEREMPUAN DI PARLEMEN (ANALISIS FRAMING DALAM PEMBERITAAN VOAINDONESIA.COM DAN MEDIAINDONESIA.COM)
}

\author{
Endang Tri Santi
}

\author{
Dosen Program Studi Ilmu Komunikasi, Fakultas Ilmu Sosial dan Ilmu Politik \\ Universitas Islam Syekh Yusuf Tangerang, Indonesia \\ 15118 \\ Email: etrisanti@unis.ac.id
}

\begin{abstract}
ABSTRAK
Representasi perempuan di panggung politik masih menjadi isu menarik dengan berbagai polemik. Kebijakan yang harus sesuai dengan cita-cita pengarusutamaan gender, kekerasan terhadap perempuan, diskriminasi dan sebagainya menjadi konsen pemerintah dengan mengeluarkan kebijakan 30\% kuota perempuan untuk duduk di kursi Parlemen. Dari permasalahan tersebut, peran politisi perempuan di Parlemen yang harusnya terlihat, sehingga dapat ditelaah bagaimana sesungguhnya representasi politisi perempuan di parlemen. Melalui berbagai pemberitaan yang muncul juga dapat kita lihat apakah kemudian media masih bias gender dalam memberitakan politisi perempuan, karena sangat mempengaruhi opini yang berkembang di masyarakat, sehingga citra politisi perempuan di Parlemen dapat terukur positif atau negatif. Penelitian ini menggunakan metode kualitatif dengan menggunakan pendekatan analisis framing dari Robert N. Entman di mana dalam penguraiannya menggunakan teori gender dengan tujuan untuk mengetahui bagaimana representasi citra politisi perempuan di Parlemen pada pemberitaan di Voaindonesia.com dan Mediaindonesia.com. Hasil penelitian menunjukkan representasi citra politisi perempuan di Parlemen masih kurang adanya kepercayaan dari masyarakat yang disebabkan adanya ketimpangan gender, kurangnya akses, dianggap kurang konsisten, kurang pengalaman dan minim strategi. Oleh karenanya rekomendasi yang diajukan perempuan harus diberikan akses untuk mendapatkan pendidikan dan pengalaman politik untuk mengembalikan citra positif atau kepercayaan masyarakat terhadap kinerja perempuan di Parlemen. Selanjutnya peneliti berharap semoga jurnal ini dapat memberikan kontribusi bagi perkembangan keilmuan dan menjadi gambaran pihak-pihak terkait dalam upaya membangun iklim politik yang memiliki kesetaraan gender.
\end{abstract}

Kata kunci: Representasi, politisi perempuan, gender, politik

\section{ABSTRACT}

The representation of women on the political stage is still an interesting issue with various polemics. Policies that must be in line with the ideals of gender mainstreaming, violence against women, discrimination and so on become government concentrations by issuing a 30\% quota policy for women to sit in Parliament. From these problems, the role of women politicians in Parliament should be seen, so that it can be explored how the actual representation of women politicians in parliament. Through the various reports that emerge we can also see whether then the media is still gender biased in reporting women politicians, because it greatly influences the opinions that develop in society, so that the image of women politicians in Parliament can be measured positively or negatively. This study uses a qualitative method using the framing analysis approach from Robert $N$. Entman in which the description uses gender theory with the aim of knowing how the representation of the image of 
women politicians in Parliament in reporting on Voaindonesia.com and Mediaindonesia.com. The results showed the representation of the image of women politicians in Parliament was still lack of trust from the community due to gender inequality, lack of access, considered less consistent, lack of experience and minimal strategy. Therefore, recommendations made by women must be given access to education and political experience to restore the positive image or public trust in women's performance in Parliament. Furthermore, the researchers hope that this journal can contribute to the development of science and be a picture of the parties involved in efforts to build a political climate that has gender equality.

Keywords: Representation, women politicians, gender, politics

\section{Pendahuluan}

Di era reformasi perempuan memiliki hak dan kesempatan yang sama dengan lakilaki dalam ruang politik. Bahkan kebijakan pemerintah mencanangkan kuota minimal 30\% perempuan sebagai syarat partai politik dalam pencalonan anggota legislatif menjadi salah satu bentuk keseriusan pemerintah untuk mendorong kehadiran dan keterbukaan terhadap perempuan di ranah publik. Akan tetapi tidak dapat dipungkiri Indonesia masih sangat kental dengan budaya patriarki yang menempatkan perempuan sebagai makhluk kedua setelah laki-laki. Perempuan di definisikan makhluk yang ruang geraknya di kasur, dapur, dan sumur. Hingga kini anggapan tersebut masih berkembang di masyarakat.

Secara faktual, Indonesia telah banyak mencetak nama-nama tokoh perempuan yang pernah menduduki jabatan strategis dalam pemerintahan. Seperti, menteri negara, anggota parlemen, gubernur dan bupati bahkan presiden. Namun asumsi yang menganggap perempuan hanya sebagai insan feminin dan lemah dalam hal-hal tertentu masih sangat berkembang. Rancangan Undang-undang kesetaraan dan Keadilan Gender (RUU KKG) dihadirkan dengan harapan segala bentuk kebijakan yang dikeluarkan pemerintah tentunya mempertimbangkan aspek keadilan gender. Meskipun hasil pemilu anggota legislatif 2014 belum menunjukkan pencapaian yang signifikan atas keterwakilan perempuan di DPR yakni baru mencapai $17.34 \%$ dari $30 \%$ keterwakilan yang diharapkan (Cangara,
2016:325). Begitu pun pemilu 2019 juga belum mencapai $30 \%$ keterwakilan perempuan di DPR, meskipun secara presentase mengalami kenaikan dibandingkan pemilu yang sebelumnya.

Banyaknya permasalahan perempuan, seperti kekerasan pada perempuan, pelecehan terhadap perempuan, diskriminasi terhadap perempuan, kesenjangan antara perempuan dan laki-laki, pernikahan di bawah umur, dan permasalahan lainnya, ikut mendorong hadirnya perempuan dalam pemilu sebagai salah satu cara agar kepentingan perempuan dapat terakomodir melalui perwakilan perempuan di parlemen. Maksud dari keterwakilan perempuan adalah pemberian kesempatan dan kedudukan yang sama bagi perempuan dalam bidang eksekutif, yudikatif, dan legislatif agar dapat melaksanakan perannya menuju keadilan dan kesetaraan gender (Astrik, 2009:28). Sehingganya perempuan perlu ikut berpartisipasi dalam politik, yang bukan hanya sebagai pemilih saja, namun juga sebagai kandidat yang kemudian dapat dipilih untuk berperan dalam pengambilan kebijakan. Terdapat beberapa faktor yang dapat mendorong munculnya partisipasi perempuan dalam politik (Cangara, 2016:324) , yakni; pertama, sistem politik Indonesia yang memberikan peluang $30 \%$ bagi perempuan. Kedua, sektor pendidikan formal yang membuat perempuan memiliki peluang untuk maju. Ketiga, kemajuan teknologi yang mampu mengantarkan perempuan untuk mengakses pengetahuan dan keterampilan. 
Representasi perempuan dalam Parlemen menjadi sebuah tema yang selalu hangat dan menarik untuk diperbincangkan. Terlebih ketika kita kaitkan dengan bahasan gender yang ikut mempengaruhi keterlibatan perempuan dalam politik (dalam Rasyidin \& Aruni, 2016:2). Tema perempuan dalam politik juga tidak luput dari pemberitaan yang dimunculkan dalam media massa yang dengan kekuatannya kemudian dapat mendorong adanya opini publik. Akan tetapi yang amat disayangkan adalah masih banyak media massa yang mendiskreditkan peran perempuan di bidang politik dalam sebuah pemberitaan. Seperti yang dikatakan Bostrom (dalam Henry \& ida, 212:159) media kerap kali memberikan pertanyaan kepada politisi perempuan yang berbeda dengan yang ditanyakan terhadap politisi laki-laki. Selain itu, media pun masih kerap mendeskripsikan politisi perempuan dengan berbagai cara dan kata-kata yang lebih menonjolkan perempuan di ranah tradisional, penampilan perempuan di publik, perilaku perempuan di masyarakat, sampai bagaimana gaya rambut peremuan dan kebiasaan perempuan menghabiskan uang untuk berbelanja online, yang kesemuanya itu tidak ada pengaruhnya terhadap kemampuan perempuan dalam mengambil peran di politik.

Secara garis besar jumlah keterlibatan perempuan di politik memang menunjukkan progres yang menggembirakan. Partisipasi politik perempun memang tidak lagi hanya memberikan suara, tetapi juga dilakukan dengan cara perempuan mencalonkan diri dalam kancah politik. Namun kondisinya tidak menunjukkan perubahan yang signifikan, apalagi ketika media massa tidak menunjukkan dukungannya melalui teknik liputan dan framing perempuan dalam diskursus politik. Terlebih ketika gambaran stereotype yang masih menjadi frame politisi perempuan yang kemudian akan ikut mempengaruhi kuat atau lemahnya perempuan dalam politik. Sehingga citra keterwakilan Perempuan dalam Parlemen masih saja kurang di mata masyarakat, dengan kata lain publik masih minim kepercayaan terhadap keterwakilan perempuan di Parlemen.

Merujuk pada penelitian sebelumnya yang ditulis oleh Yenny Yunita dan Dedeh Fardiah di Jurnal Mediator dengan judul Citra Caleg Perempuan dalam "Framing" Media "Online" menggambarkan bagaimana citra caleg perempuan dalam framing Kompas.com dan Detik.com yakni perempuan yang berani mencalonkan diri kebanyakan dari kalangan artis atau incumbent yang dekat dengan pejabat penting. Sehingga dalam kesimpulannya citra caleg perempuan hanya mengandalkan kecantikan, penampilan dan kepopuleran untuk menarik pemilihnya. Oleh karenanya rekomendasi penyelesaian yang ditawarkan adalah peranan perempuan hendaknya meningkatkan sisi pengetetahuan, pendidikan, dan peran publiknya di dunia politik.

Dari uraian di atas, peneliti tertarik untuk mencoba menangkap bagaimana pembingkaian berita yang ada di Voaindonesia.com dan Mediaindonesia.com pada periode pemberitaan pasca pemilu 2019 yang menggambarkan politisi perempuan yang berhasil duduk di parlemen dan bahasan tentang bagaimana citra politisi perempuan di parlemen yang kemudian mau tidak mau menjadi sebuah wacana bagaimana sesungguhnya keterwakilan perempuan di ranah politik. Tujuannya kemudian adalah melihat apakah terjadi bias gender yang dirasakan oleh politisi perempuan dalam parlemen yang dapat kita lihat dari framing sebuah berita.

\section{Metode Penelitian}

Metode yang digunakan dalam penelitian ini adalah metode kualitatif dengan menggunakan pendekatan analisis framing dari Robert N. Entman. Analisis framing merupakan salah satu pendekatan untuk menganalisis sebuah fenomena komunikasi, dalam penelitian ini untuk menganalisis teks media. Adapun objek dalam penelitian ini adalah pemberitaan yang ada di 
Voaindonesia.com dan Mediaindonesia.com yang di dalamnya memuat berita politisi perempuan yang ada di parlemen. Peneliti menggunakan analisis framing dari Robert N. Entman dikarenakan pendekatan yang ditawarkan oleh Entman lebih sesuai dengan permasalahan yang hendak diteliti, yakni bagaimana berita politik menggambarkan suatu peristiwa. Selain itu, dalam komunikasi politik, Entman mampu melihat bagaimana kekuatan teks yang ada dalam berita politik tersebut. Tahapan awal dalam penelitian ini, peneliti menggunakan analisis tekstual untuk menemukan muatan yang ada dalam berita di Voaindonesia.com dan Mediaindonesia.com. kemudian data tersebut di analisis dengan model framing yang peneliti gunakan.

\section{Hasil dan Pembahasan}

Melalui analisis Framing (Eryanto, 2002:24) yakni pendekatan untuk mengetahui

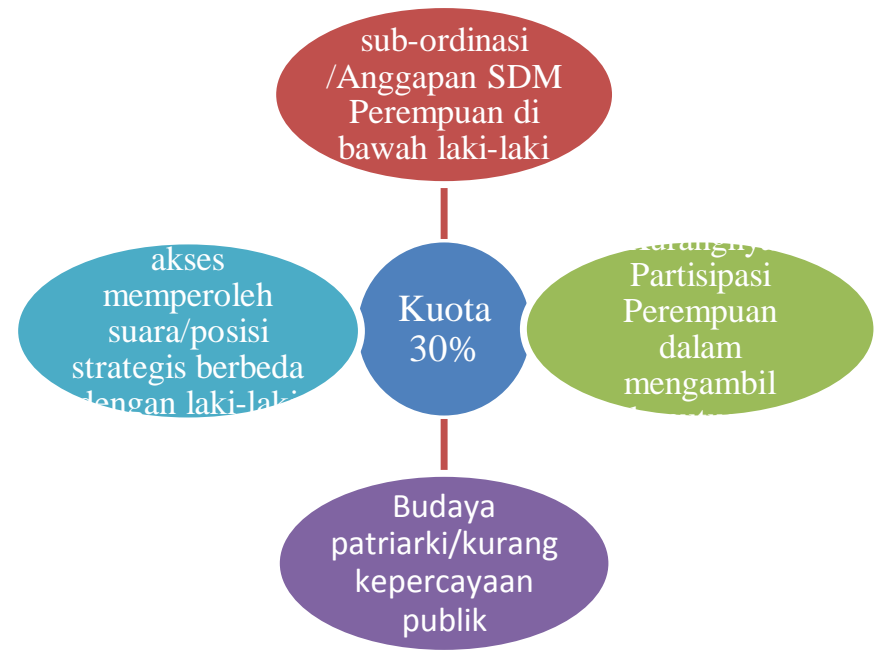

Gambar 1 Define Problems (pendefinisan masalah) Voaindonesia.com

Define Problems (Definisi masalah) merupakan elemen pertama kali yang dapat kita lihat sebagai master frame (bingkai utama), yang akan menggambarkan bagaimana isu atau peristiwa dipahami secara keseluruhan. Seperti yang telah digambarkan di atas menekankan bahwa bagaimana seorang wartawan memahami sebuah isu atau peristiwa mengenai representasi perempuan dalam parlemen pada pemberitaan 2019, yakni; Belum tercapainya kuota $30 \%$ kursi bagaimana perspektif yang digunakan oleh pewarta dalam memilih isu dan menulis berita. Kemudian perspektif tersebutlah yang akan menjadi acuan dalam menentukan fakta apa yang akan diambil, fakta mana saja yang akan lebih ditonjolkan, serta akan ke mana arah berita tersebut. Maka penulis akan membedah pemberitaan yang ada di Voaindonesia.com dan Mediaindonesia.com dengan menggunakan Framing versi Robert Enmant yang di dalamnya terdapat empat elemen, yakni; pendefinisian masalah, mempekirakan penyebab masalah, membuat keputusan moral, dan menekankan penyelesaian.

Framing Voaindonesia.com pada pemberitaan tentang representasi citra politisi perempuan di parlemen.

\section{Define Problems (pendefinisian masalah)}


dari perempuan lokal yang dianggap dapat mendulang suara, serta ada hubungan kerabat dengan pejabat daerah tertentu yang dianggap ada dukungan logistik. Kurangnya partisipasi perempuan dalam parlemen yang dianggap tidak memiliki pengaruh dalam pengambilan kebijakan. Perempuan di parlemen tidak diberikan posisi atau tempat strategis sehingga keterwakilan perempuan di parlemen seolah hanya sebagai pajangan semata.

Secara umum kesimpulan perihal definisi masalah yang dilakukan oleh Voaindonesia.com dalam beberapa berita terkait politisi perempuan dalam Parlemen tahun 2019 yakni politisi yang berhasil menduduki Parlemen dari kalangan artis dan juga yang memiliki kekerabatan terhadap pejabat tertentu yang dianggap memiliki dukungan logistik. Selain itu keterwakilan politisi perempuan di Parlemen dianggap hanya pajangan semata atau dengan kata lain kurang adanya sumbangsih perubahan dikarenakan politisi perempuan tidak diberikan akses untuk mendapatkan posisi atau tempat strategis yang di mana dalam pengambilan keputusan atas kebijakan politisi perempuan masih lemah. Definisi masalah berikutnya masih berkembangnya budaya patriarki yang mempengaruhi kepercayaan publik terhadap politisi perempuan yang dianggap kurang mampu mewakili di ranah politik.

\section{Diagnose cause (penyebab masalah)}

Media masih

mempertanyakan

perihal pribadi dalam

wawancara kepada

politisi perempuan

dengan baik terhadap

politisi perempuan dan

hanya memenuhi syarat

\section{perempuan kurang terdengar} saja.

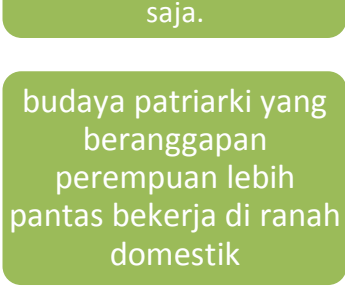

Gambar 2 Diagnose cause (penyebab masalah) Voaindonesia.com

Diagnose causes merupakan elemen framing untuk membingkai penyebab masalah yang muncul terkait apa (what) atau siapa (who) dalam pemberitaan yang dibuat oleh media Voaindonesia.com terkait politisi di Parlemen. Permasalahan yang muncul yakni keterwakilan aspirasi perempuan kurang terdengar sehingga tidak dapat menyampaikan dan membuat kebijakan yang perspektif gender dengan baik. perempuan tidak memiliki kesempatan berargumentasi mengenai kebijakan publik dengan baik, dikarenakan beberapa faktor, yakni ; Media masih mempertanyakan perihal pribadi dalam wawancara kepada politisi perempuan dan partai politik tidak melakukan pengkaderan dengan baik terhadap politisi perempuan, sehingga membuat perempuan belum mengetahui peta politik dengan baik. Setelah itu, permasalahan yang muncul berikutnya adalah masih banyaknya yang mempertanyakan soal kemampuan perempuan dalam politik, hal ini dikarenakan budaya patriarki yang beranggapan perempuan lebih pantas bekerja di ranah domestik.

Secara umum kesimpulan perihal penyebab masalah yang dilakukan oleh Voaindonesia.com dalam beberapa berita 
terkait politisi perempuan dalam Parlemen tahun 2019 yakni kurang terdengarnya aspirasi perempuan yang terbukti dengan beberapa undang-undang tentang perempuan yang masih meggantung yang disebabkan oleh beberapa faktor yakni partai politik tidak melakukan pengkaderan dengan baik sehingga politisi perempuan yang muncul hanya mengandalkan kepopuleran dan hubungan dengan pejabat tertentu tanpa menimbang kemampuan dalam bidang politik, masih banyak media yang memberitakan politisi perempuan di ranah pribadi, dan anggapan perempuan lebih pantas bekerja di ranah domestik sehingga daya juang politisi perempuan kurang bersuara. Sehingga dengan kata lain isu ketimpangan gender masih sangat mempengaruhi peran perempuan di ranah politik yang kemudian menyebabkan citra politisi perempuan dalam Parlemen dinilai kurang.

\section{Make Moral Judgement (membuat keputusan moral)}

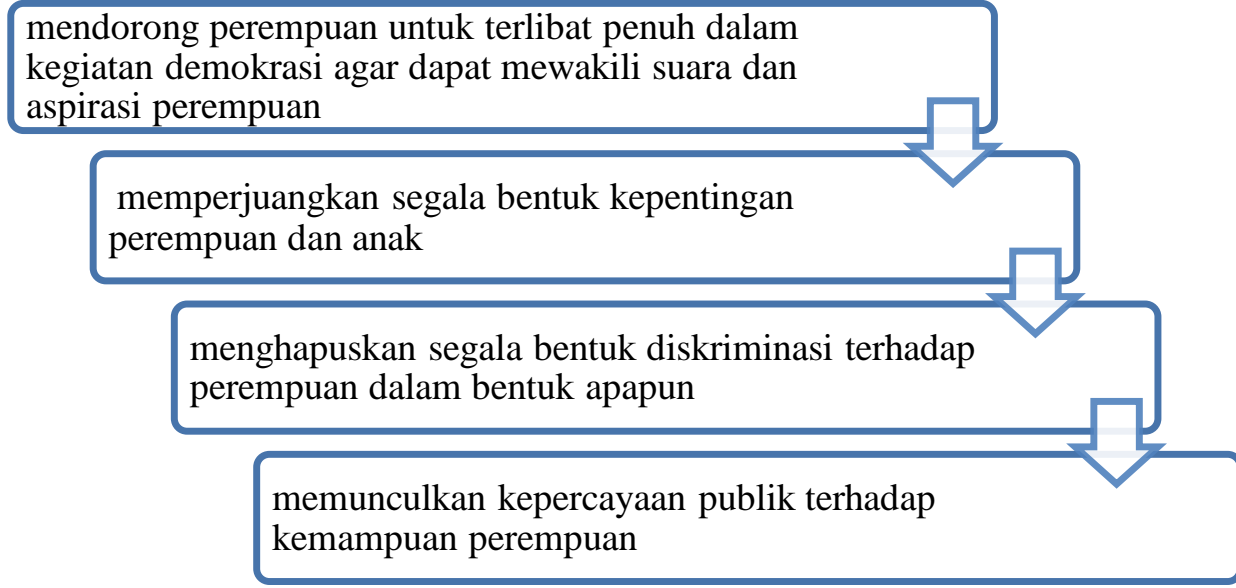

Gambar 3 Make Moral Judgement membuat keputusan moral Voa.indonesia.com

Pada elemen ketiga ini keputusan moral yang dilakukan oleh Voaindonesia.com dalam pemberitaan representasi perempuan dalam parlemen terdapat beberapa alasan dasar, yakni terlibat penuh dalam kegiatan demokrasi yang bukan hanya memilih tetapi juga ikut dipilih mewakili suara dan aspirasi perempuan. Perempuan di parlemen ingin memperjuangkan segala bentuk kepentingan perempuan dan perlindungan anak. Menghapuskan segala bentuk diskriminasi terhadap perempuan dalam bentuk apapun, seperti pelecehan seksual, kekerasan dalam rumah tangga, perempuan dianggap makhluk lemah dan lainnya. Terakhir adalah representasi perempuan dalam politik untuk memunculkan kepercayaan publik terhadap kemampuan perempuan dalam memimpin, yang selama ini hanya dilakukan oleh kaum laki-laki sebagai pengambil kebijakan utama.

Secara umum kesimpulan keputusan moral yang dilakukan oleh Voaindonesia.com dalam beberapa berita terkait politisi perempuan dalam Parlemen tahun 2019 yakni politisi perempuan yang hadir dalam Parlemen sebenarnya ingin mewakili suara perempuan agar kebijakan yang dibuat oleh pemerintah lebih responsif gender, sehingga dapat meminimalisir marginalisasi terhadap perempuan, pelecehan perempuan, kekerasan terhadap perempuan dan bentuk diskriminasi lainnya.

\section{Treatment Recommendation (menekankan penyelesaian)}




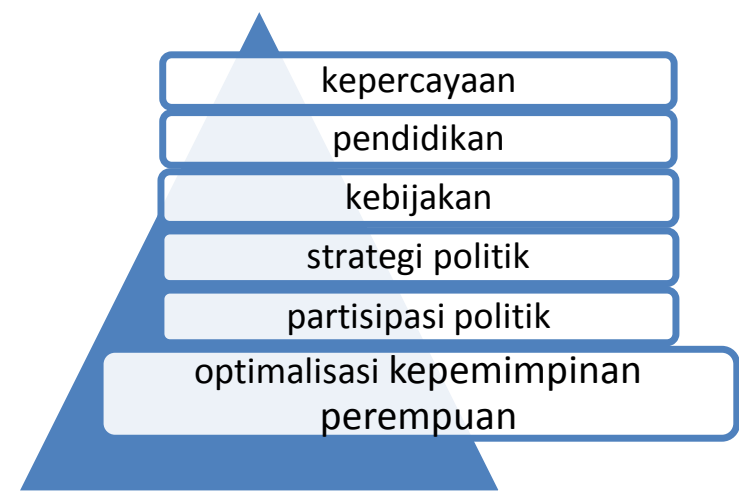

Gambar 4. Treatment Recommendation (membuat keputusan moral)

Pada elemen keempat yakni treatment recommendation (menekankan penyelesaian), yakni jalan untuk menyelesaikan masalah yang tergantung pada bagaimana sebuah peristiwa dilihat dan siapa yang dipandang sebagai masalah. Adapun rekomendasi terhadap pemberitaan perempuan dalam parlemen adalah sebagai berikut, harus adannya pengoptimalisasi kepemimpinan perempuan dengan memberikan kepercayaan kepada perempuan bahwa perempuan mampu menjadi seorang pemimpin. Mendorong perempuan ikut aktif dalam partisipasi politik, bukan hanya sebagai penonton bagi kaum laki-laki dalam mengambil kebijakan. Partai politik maupun pemerintahan harus memiliki strategi agar perempuan dapat terplih berdasarkan kompetisinya bukan hanya populernya saja. Keterwakilan perempuan dalam parlemen tentu akan menghasilkan sebuah kebijakan yang pro terhadap perempuan. Keterwakilan perempuan dalam politik akan maksimal apabila perempuan diberikan kesempatan memperoleh pendidikan politik dengan baik.

Secara umum kesimpulan rekomendasi penyelesaian yang dilakukan oleh Voaindonesia.com dalam beberapa berita terkait politisi perempuan dalam Parlemen tahun 2019 yakni untuk mewujudkan keterwakilan politisi perempuan dalam Parlemen perlu adanya pengoptimalan kepempimpinan perempan di Parlemen sehingga keputusan kebijakan berada di tangan perempuan. Pengoptimalan tersebut juga dapat diwujudkan dengan memacu perempuan untuk ikut lebih aktif berpartisipasi politik, strategi politik harus lebih ditingkatkan, perempuan diberikan pendidikan yang baik untuk menambah pengetahuan, serta memberikan kepercayaan kepada perempuan untuk memimpin dalam Parlemen.

Framing Mediaindonesia.com pada pemberitaan tentang representasi citra politisi perempuan di parlemen

1. Define Problems (pendefinisian masalah) 


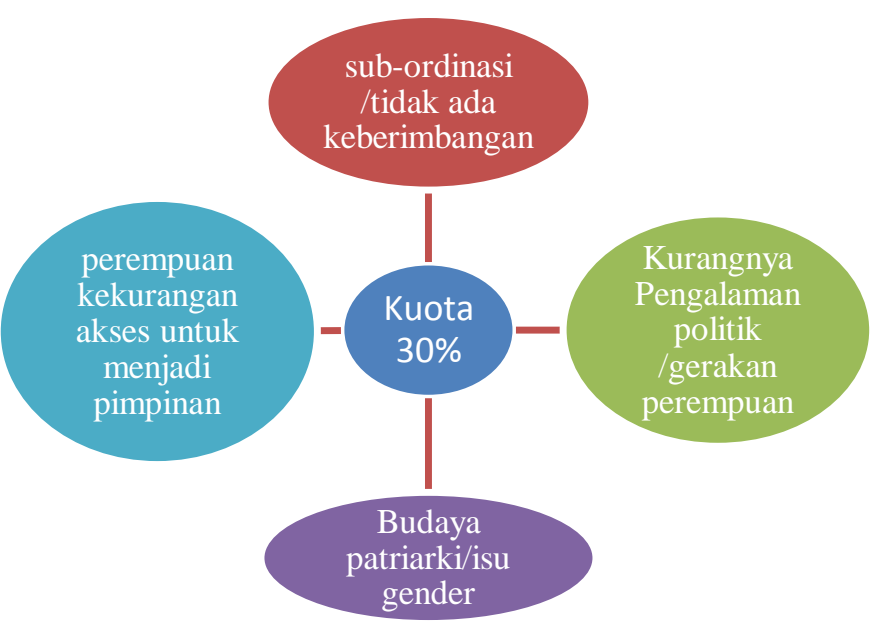

Gambar 5. Define Problems (pendefinisan masalah) Mediaindonesia.com

Define Problem (Definisi masalah) merupakan elemen pertama kali yang dapat kita lihat sebagai master frame (bingkai utama), yang akan menggambarkan bagaimana isu atau peristiwa dipahami secara keseluruhan. Seperti yang telah digambarkan di atas menekankan bahwa bagaimana seorang wartawan memahami sebuah isu atau peristiwa mengenai representasi citra politisi perempuan dalam parlemen pada pemberitaan pasca pemilu 2019, yakni perempuan di parlemen tidak mewakili suara perempuan karena tidak memiliki keberimbangan dengan politisi lakilaki yakni kuota yang tidak mencapai $30 \%$. Hal tersebut dikarenakan; kurang adanya akses perempuan untuk menjadi pimpinan di parlemen, Kurangnya pengalaman politik atau gerakan perempuan dalam politik, tidak adanya keberimbangan antara perempuan dan lakilaki, sampai dengan isu gender yang berkembang di masyarakat ikut mempengaruhi keterwakilan perempuan di parlemen.

Secara umum kesimpulan perihal definisi masalah yang dilakukan oleh Mediaindonesia.com dalam beberapa berita terkait politisi perempuan dalam Parlemen tahun 2019 yakni tidak tercapainya kuota 30\% perempuan di Parlemen memberikan arti bahwa keterwakilan perempuan di Parlemen tidak dapat maksimal karena tidak ada keberimbangan antara politisi perempuan dan laki-laki. Tidak tercapainya kuota yang diharapkan tentu penyebabnya banyak faktor, diantaranya kurangnya pengalaman perempuan di ranah politik dan masih terdapat bias gender yang berkembang di masyarakat, sehingga yang dipilih hanya berdasarkan kepopularitasan semata bukan meninjau dari keterampilan.

2. Diagnose cause (penyebab masalah)

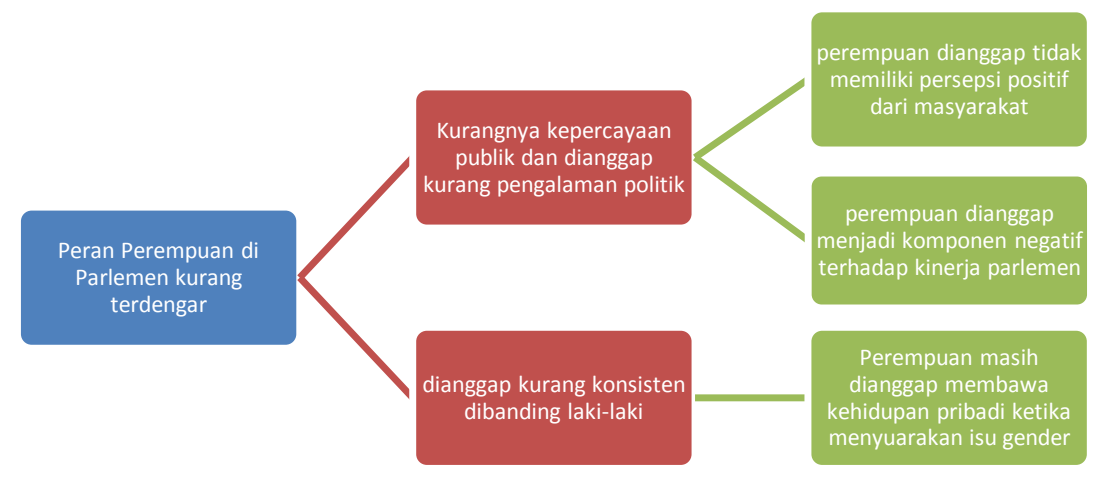

Gambar 6. Diagnose cause (penyebab masalah) 
Diagnose cuses merupakan elemen framing untuk membingkai penyebab masalah yang muncul terkait apa (what) atau siapa (who) dalam pemberitaan yang dibuat oleh mediaindonesia.com terkait politisi di parelemen. Permasalahan yang muncul yakni keterwakilan aspirasi perempuan kurang terdengar sehingga tidak dapat menyampaikan dan membuat kebijakan yang perspektif gender dengan baik. Kurangnya konsistensi perempuan di parlemen yang membawa isu gender, sehingga kalah dengan suara laki-laki yang dianggap lebih konsisten. Kurangnya kepercayaan publik terhadap politisi perempuan yang dianggap kurang pengalaman politik. Politisi perempuan dianggap tidak memiliki persepsi positif dari masyarakat. Secara umum perempuan dianggap menjadi komponen negatif terhadap kinerja parlemen.
Secara umum kesimpulan perihal penyebab masalah yang dilakukan oleh Mediaindonesia.com dalam beberapa berita terkait politisi perempuan dalam Parlemen tahun 2019 yakni kebijakan yang perspektif gender tidak akan terwujud dengan baik jika aspirasi perempuan tidak dapat tersampaikan dengan baik melalui perwakilan perempuan di Parlemen. Laki-laki masih mendominasi pengambilan keputusan dalam pengambilan kebijakan. Penyebab lainnya adalah perempuan dinilai kurang konsisten sehingga persepsi masyarakat kurang positif dan tentu akan berpengaruh terhadap kinerja politisi perempuan di Parlemen.

3. Make Moral Judgement (membuat keputusan moral)

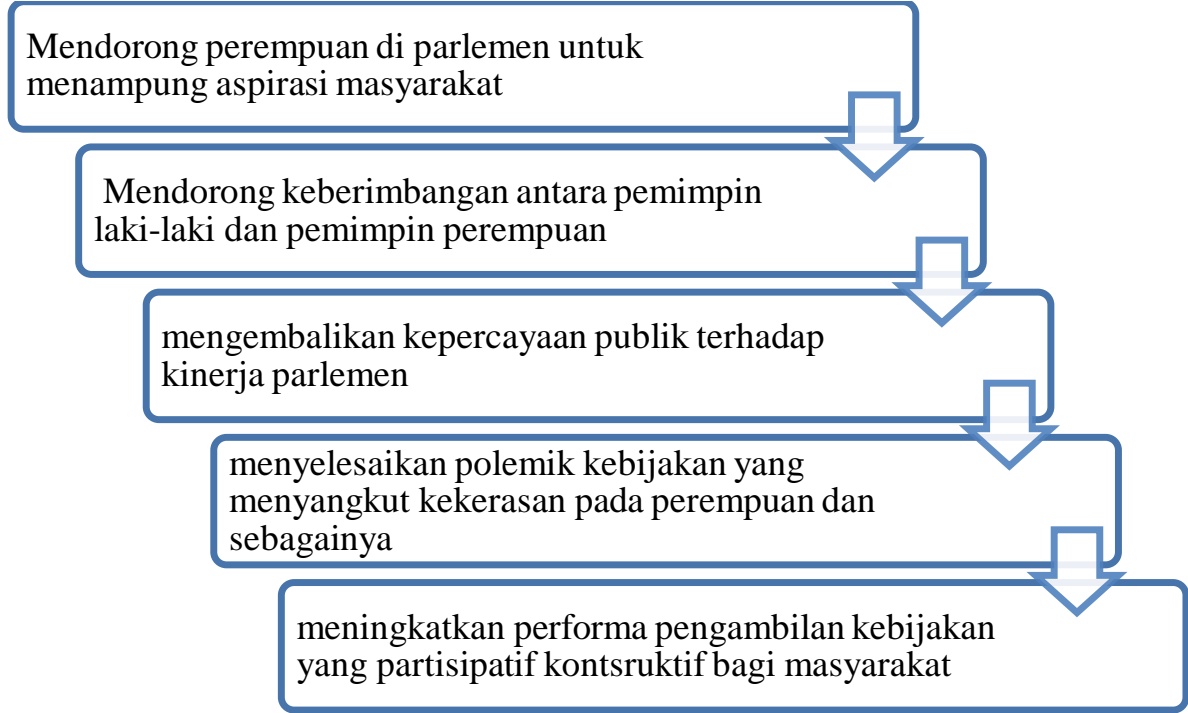

Gambar 7. Make Moral Judgement (membuat keputusan moral)

Pada elemen ketiga ini keputusan moral yang diajukan oleh Mediaindonesia.com dalam pemberitaan representasi citra politisi perempuan dalam parlemen terdapat beberapa alasan dasar, yakni Perempuan hadir dalam parlemen untuk menampung aspirasi masyarakat. Harus adanya keberimbangan antara pemimpin laki-laki dan pemimpin perempuan. Perempuan harus mampu mengisi kekosongan di parlemen sebagai pengambil kebijikan atau pembuat undang-undang. Mengembalikan kepercayaan publik terhadap kinerja parlemen. Perempuan harus mampu menyelesaikan polemik kebijakan yang menyangkut kekerasan pada perempuan dan sebagainya dan Politisi perempuan harus lebih meningkatkan performa pengambilan kebijakan yang partisipatif kontsruktif bagi masyarakat.

Secara umum kesimpulan perihal keputusan moral yang dilakukan oleh Mediaindonesia.com dalam beberapa berita terkait politisi perempuan dalam Parlemen 
tahun 2019 yakni harus adanya keberimbangan antara pemimpin perempuan dan pemimpin laki-laki di Parlemen sehingga kebijakan yang responsif gender segera terwujud. Politisi perempuan harus mampu mengembalikan citra Parlemen di mata publik sehingga kepercayaan masyarakat terhadap kinerja perempuan dapat muncul, dengan begitu representasi politisi perempuan di Parlemen mendapatkan kesan positif melalui performa yang meningkat.

4. Treatment Rekcommendation (menekankan penyelesaian)

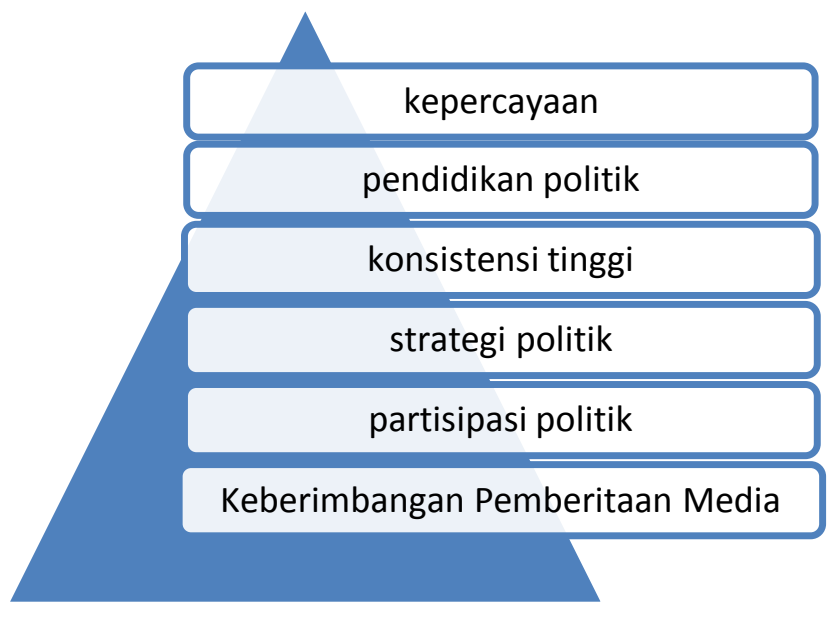

Gambar 8. Treatment Rekcommendation (membuat keputusan moral)

Pada elemen ini digunakan untuk menilai apa yang dikehendaki oleh wartawan dan bagaimana penyelesaian masalahnya. Adapun rekomendasi penyelesaian masalah yang muncul sebagai solusi moral yang ditekankan media ketika mengangkat berita mengenai politisi perempuan di parlemen, diantaranya ; Perempuan harus diberikan kepercayaan untuk menjadi pemimpin dalam membuat kebijakan. Perempuan harus mulai diberikan pendidikan politik meskipun belum terjun langsung sebagai anggota dewan, dengan begitu ketika perempuan mencalonkan diri, perempuan sudah memiliki kesiapan. Dalam menyuarakan isu gender, mustinya perempuan memiliki konsistensi tinggi, sehingga tidak melulu disebut konsistensi perempuan dalam menjadi pengambil kebijakan masih di bawah dibanding laki-laki. Perempuan harus mampu melihat permasalahan perempuan dari kaca mata publik, bukan membawa isu pribadi. Media yang memberitakan soal politisi perempuan hendaknya memberitakan soal keberimbangan antara politisi perempuan dan laki-laki.

Secara umum kesimpulan perihal rekomendasi penyelesaian yang dilakukan oleh Mediaindonesia.com dalam beberapa berita terkait politisi perempuan dalam Parlemen tahun 2019 yakni perempuan harus diberikan pendidikan politik meskipun belum terjun langsung ke ranah politik dengan begitu ketika perempuan ikut mencalonkan diri maka sudah memiliki kesiapan. Representasi citra politisi perempuan di Parlemen akan dinilai positif apabila masyarakat mampu memberikan kepercayaan kepada politisi perempuan di Parlemen. Begitu pun sebaliknya politisi perempuan harus menunjukkan konsistensi dalam menyuarakan isu gender dalam sumbangsih pengambilan kebijakan.

\section{Kesimpulan}

Framing pemberitaan tentang politisi perempuan dalam parlemen di Voaindonesia.com dan Mediaindonesia.com mendefinisikan masalah representasi citra 
politisi perempuan dalam parlemen yakni kurangnya keterwakilan suara perempuan dalam parlemen yang ditandai dengan masih banyaknya kebijakan atau undang-undang yang berhubungan dengan perempuan ysng masih mengambang atau dalam pengambilan keputusannya masih didominasi oleh laki-laki. Representasi citra politisi perempuan dianggap minim tentunya diakibatkan oleh beberapa faktor, diantaranya ketidaksiapan perempuan sendiri dalam ikut berpartisipasi dalam mencalonkan diri sebagai anggota Parlemen yang dapat kita lihat melalui belum tercapainya kuota $30 \%$ perempuan, strategi partai politik yang kurang menempatkan perempuan di urutan no.1 dalam pemilu, serta masih berkembangnya budaya patriarki di masyarakat sehingga mempengaruhi kepercayaan publik terhadap kepemimpinn perempuan, di tambah lagi pemberitaan di media yang masih banyak mengenai kehidupan pribadi para politisi perempuan bukan pertanyaan soal isu politik atau negara. Hadirnya perempuan dalam politik tentu membawa angin segar untuk menyampaikan aspirasi yang berkeadilan gender, untuk itu Voaindonesia.com dan Mediaindonesia.com memetakan bagaimana agar representasi citra politisi perempuan di Parlemen terdengar, yakni dengan cara memberikan pendidikan politik dan pengalaman politik kepada perempuan, strategi partai politik dan keberimbangan untuk menempatkan perempuan pada urutan no.1 dalam pemilu, memberikan akses kepada perempuan untuk menjadi pemimpin di parlemen, publik harus memberikan kepercayaan kepada perempuan, dan politisi perempuan harus konsisten dalam menyuarakan keadilan gender.

\section{Daftar Pustaka}

Anugrah, Astrik. (2009). Keterwakilan Perempuan dalam Politik. Jakarta: Pancuran Alam

Cangara, Hafied. (2016). Edisi Revisi Komunikasi Politik (Konsep, Teori, dan Strategi). Jakarta: PT. Raja Grafindo Persada

Eriyanto. (2002). Analisis Framing, Konstruksi Ideologi dan Politi Media. Yogyakarta: LkiS

Rasyidin \& Aruni, Fidhia. (2016). Gender dan Politik (Keterwakilan Wanita dalam Politik). Sulawesi:UNIMALPRESS

Subiakto, Henry \& Ida, Rachmah. (2012). Komunikasi Politik, Media, \& Demokrasi. Jakarta: Kencana Prenada Media Group

Yunita, Yennita \& Fardiah, Dedeh. (2017). Citra Caleg Perempuan dalam "Framing" Media "online". Mediator, Vol 10, 75-86 